\title{
A Review of the Plantar Pressure Distribution Effects from Insole Materials and at Different Walking Speeds
}

\author{
Fahni Haris ${ }^{1,2} \mathbb{D}^{\mathbb{D}}$, Ben-Yi Liau ${ }^{3}$, Yih-Kuen Jan ${ }^{4,5,6}{ }^{\mathbb{D}}$, Veit Babak Hamun Akbari ${ }^{7}$, Yanuar Primanda ${ }^{1}$, \\ Kuan-Han Lin ${ }^{2}$ and Chi-Wen Lung $4,7, *$ (D)
}

1 School of Nursing, Universitas Muhammadiyah Yogyakarta, Yogyakarta 55183, Indonesia; fahni.h@umy.ac.id (F.H.); yanuarprimanda@umy.ac.id (Y.P.)

2 Department of Healthcare Administration, Asia University, Taichung 41354, Taiwan; okonkwolin@asia.edu.tw

3 Department of Biomedical Engineering, Hungkuang University, Taichung 433304, Taiwan; byliau@hk.edu.tw

4 Rehabilitation Engineering Lab, University of Illinois at Urbana-Champaign, Champaign, IL 61820, USA; yjan@illinois.edu

5 Kinesiology and Community Health, University of Illinois at Urbana-Champaign, Champaign, IL 61820, USA

6 Computational Science and Engineering, University of Illinois at Urbana-Champaign, Champaign, IL 61820, USA

7 Department of Creative Product Design, Asia University, Taichung 41354, Taiwan; 109711569@live.asia.edu.tw

* Correspondence: cwlung@asia.edu.tw

check for

updates

Citation: Haris, F.; Liau, B.-Y.; Jan, Y.-K.; Akbari, V.B.H.; Primanda, Y.; Lin, K.-H.; Lung, C.-W. A Review of the Plantar Pressure Distribution Effects from Insole Materials and at Different Walking Speeds. Appl. Sci. 2021, 11, 11851. https://doi.org/ 10.3390/app112411851

Academic Editor: Zimi Sawacha

Received: 18 November 2021

Accepted: 9 December 2021

Published: 13 December 2021

Publisher's Note: MDPI stays neutral with regard to jurisdictional claims in published maps and institutional affiliations.

Copyright: (C) 2021 by the authors. Licensee MDPI, Basel, Switzerland. This article is an open access article distributed under the terms and conditions of the Creative Commons Attribution (CC BY) license (https:/ / creativecommons.org/licenses/by/ $4.0 /)$.
Featured Application: (A) Walking speeds and insole material are common modulating factors that decrease peak plantar pressure (PPP) in different foot regions; (B) the appropriate walking speed for reducing PPP of the forefoot in DM was slower than non-DM; $(C)$ at a similar walking speed, DM had higher PPP than non-DM; (D) the EVA is more prevalent in investigating reduced PPP in DM compared with other materials; (E) cushioning, resilience, and stiffness may be the essential mechanical properties in insole material for DM.

Abstract: Among people with diabetes mellitus (DM), the two common strategies for decreasing peak plantar pressure (PPP) to reduce diabetic foot ulcers (DFUs) risks are to modify walking speeds and to change insole materials. This study reviewed the PPP reduction based on various walking speeds and insole materials. The articles were retrieved from four major scientific databases and manual search. We identified 1585 articles, of which 27 articles were selected for full-text analysis. We found that in faster walking speeds, the forefoot PPP was higher (308 kPa) than midfoot (150 kPa) and rearfoot (251 kPa) PPP. The appropriate walking speed for reducing the forefoot PPP was about $6 \mathrm{~km} / \mathrm{h}$ for non-DM and $4 \mathrm{~km} / \mathrm{h}$ for DM people. The forefoot PPP in DM people was 185\% higher than that of non-DM people. Ethylene-vinyl acetate (EVA) insole material was the most popular material used by experts (26\%) in the forefoot and reduced $37 \%$ of PPP. In conclusion, the suitable walking speed for DM was slower than for non-DM people, and EVA was the most common insole material used to decrease the PPP under the forefoot. The clinicians might recommend DM people to walk at $4 \mathrm{~km} / \mathrm{h}$ and wear EVA insole material to minimize the DFUs.

Keywords: diabetic foot ulcer; walking intensities; plantar region; footwear; mechanical properties

\section{Introduction}

The prevalence of diabetes mellitus (DM) has been reported to increase every year. Uncontrolled DM will increase morbidity, mortality, and economic burdens [1]. The prevalence of DM in 2019 was expected to be 463 million people, growing to $10.2 \%$ (578 million people) by 2030 and 10.9\% (700 million people) by 2045 [2]. One of DM complications is diabetic foot ulcers (DFUs). It was predicted that one-third of people with DM will experience DFUs in their lives [3,4] and will develop recurrent ulcers about 0.4 times in the first year [5]. Furthermore, the risk of DFUs will increase 3 times for those who have 
DM more than 10 years, 7 times higher for those who have a level of glycated hemoglobin (HbA1c) above $86 \mathrm{mmol} / \mathrm{mL}$, and 10 times higher for those who have body mass index (BMI) above $25 \mathrm{~kg} / \mathrm{m}^{2}$ [6]. Moreover, the annual health expenses for DM, especially for diabetic foot ulcers treatment, was more than USD 10 billion in the United States [7]. Due to its high costs, DM prevention is a primary concern worldwide.

Exercise plays an essential role in DM prevention [8]. The American Diabetes Association (ADA) [9] advises that people with DM should accomplish adequate exercise to decrease the high levels of $\mathrm{HbA1c}$ [10] or excess BMI [11]. Exercise has also demonstrated its importance in maintaining a healthy body weight [11], decreasing the risk of cardiovascular diseases [12], and improving glycemic management [10]. The ADA recommends people with DM engage in vigorous aerobic exercise for at least $75 \mathrm{~min}$ per week or perform moderate-intensity aerobic exercise for at least $150 \mathrm{~min}$ per week [13]. In addition, people may perform aerobic exercise regularly to improve their health.

Healthcare professionals recommend walking as one aerobic exercise, as it is not limited by race, gender, and age [14]. For nearly four decades, walking has been the most popular exercise in physical activity [15-17]. There is a paradigm transformation regarding recommended walking to achieve health, from light-moderate exercise [16] to moderate-vigorous exercise [13]. Several studies have extensively documented that walking increases the incidence of DFUs in people with DM due to increased peak plantar pressure (PPP) [18-20]. Moreover, to resolve the increased PPP, several studies confirmed that wearing a proper insole decreases the PPP and thus the risk of DFUs [21-23]. However, as walking is performed to improve health, on the other hand, it increases the incidence of DFUs. This presents the need to decrease the PPP in walking exercises for people with DM [24]. As an answer, there are two often used strategies by researchers to decrease the PPP-namely, (1) suitable walking speed [25] and (2) suitable insole material [26].

The PPP in the plantar region may vary at different walking speeds [27]. For example, moving forward at faster walking speeds engages the plantar surface to a pronated position that might increase PPP under the forefoot [28,29]. This condition is believed to be a significant factor in affecting abnormally high PPP and further developing to the DFUs [30]. However, Lung et al. have shown that slower walking speed increases PPP in the forefoot [24]. Thus, one factor contributing to high PPP at slower walking speed was the increased foot-to-floor contact time, leading to increased PPP in the central and medial forefoot region $[24,27]$. Furthermore, the issue of reducing PPP at the plantar region is essential for DFUs prevention. Therefore, appropriate walking speeds may decrease the PPP for DM subjects under the forefoot, midfoot, and rearfoot [31,32].

The ethylene-vinyl acetate (EVA), Poron, Plastazote, and polyurethane were developed based on their function to reduce the PPP in the plantar region [33-35]. The insole has functions such as cushioning, resilience, and stiffness. The EVA has been used as an insole material in different plantar regions (forefoot, midfoot, and rearfoot) [36-38]. Single EVA as a foam-based material was excellent for energy absorption to support the rearfoot pressure reduction [39]. In addition, a combination of EVA and Poron used as foam-based insole was reported excellent as arch support and optimizing insole plugs. The insole can be customized by removing the square plugs to reduce the PPP in the forefoot region [40]. Additionally, Plastazote and polyurethane (PU) were identified as suitable materials for pressure distribution in the forefoot and rearfoot of a multi-layer Shore A insole [41]. Moreover, with its resilience, Professional Protective Technology (PPT), which provides the material strength necessary for resisting wear and tear, is reported as a high-pressure absorber to reduce the PPP in the forefoot [42]. However, foam-based Poron insole materials were reported as pressure reduction under the forefoot [43]. Therefore, insole materials are current solutions for managing the plantar region with high PPP to decrease DFUs risk [44].

Suitable walking speed, one of the aerobic exercises, is more popular and advantageous in DM people for DFUs prevention. Yet, walking still has a high risk for DFUs development in different walking speeds and plantar regions. On the other hand, different 
insole material properties may reduce the PPP in different plantar regions. However, to the best of our knowledge, no study investigates the reduction in PPP based on the plantar region in different walking speeds and different insole materials. Therefore, this study analyzes previous studies on PPP in suitable walking speeds among DM and non-DM people to find the DFUs risk features and evaluate the insole material used for DM people providing different functions for plantar regions.

\section{Materials and Methods}

We searched for published articles through four databases in April 2021, ProQuest (1983 to 2021), PubMed (1976 to 2021), ScienceDirect (1998 to 2021), and Web of Science (1977 to 2021). Search protocols were made based on search guidelines using the Patient, Intervention, Comparison and Outcome model (PICO) with the search terms: diabetes AND foot AND pressure AND insole AND walking. We performed inclusion criteria and exclusion criteria to answer the research objective. We identified additional studies based on Google Scholar conducted by previous studies [45,46].

The data were processed using the SPSS 22 program. Cohen's Kappa statistics and percentage agreement were calculated to determine whether the two reviewers agreed with the selected papers [47].

The inclusion criteria for this study were as follows: (1) participants had diabetes aged $\geq 18$ years old or healthy people; (2) studies written in English; (3) type of studies: an experimental study, non-experimental study; (4) types of exposure: had activities wearing insoles; (5) types of outcomes: at least one of walking speed, plantar pressures, plantar pressures reductions, and insole materials. The study's exclusion criterion was regarding the type of studies-namely, abstract-only publications (symposium, conference, proceeding book), protocols, review papers, systematic reviews, meta-analysis studies, and literature reviews were excluded.

The selection process based on the titles and abstracts of the studies identified in the literature against the inclusion and exclusion criteria was conducted independently by two researchers (F.H. and C.W.L.). Further, they (F.H. and C.W.L.) independently analyzed the selected studies. The agreement between two independent reviewers for screening titles and abstracts (Kappa 0.814, agreement percentage 99.2\%), full-text screening (Kappa 0.773, agreement percentage 91.9\%). A third researcher (K.H.L.) consulted disagreement between two researchers, who provided the final decision. There was no disagreement on the articles selected for this review.

A matrix table was developed to extract the data from the selected studies. The leading information to be collected was related to the two PPP aspects: (1) plantar pressure distribution at different walking speed selection and (2) insole mechanical properties.

\section{Results}

\subsection{Selected Studies}

A total of 1585 papers were found, 1580 from four databases, and five manually identified through other sources using search terms. As many as 1548 studies were included following the elimination of duplicates $(n=37)$. After reviewing the abstracts, we removed 1511 articles and retrieved 37 papers for full-text analysis. We excluded ten studies; eight studies lacked specific insoles, one discussed artificial intelligence, and one analyzed insole cost effectiveness. We included 27 articles for the final analysis. Figure 1 describes the flow diagram for the selection process of studies included in this review. Figure 2 describes the published paper on PPP reduction strategies. 




Figure 1. Flow diagram for study selection. 


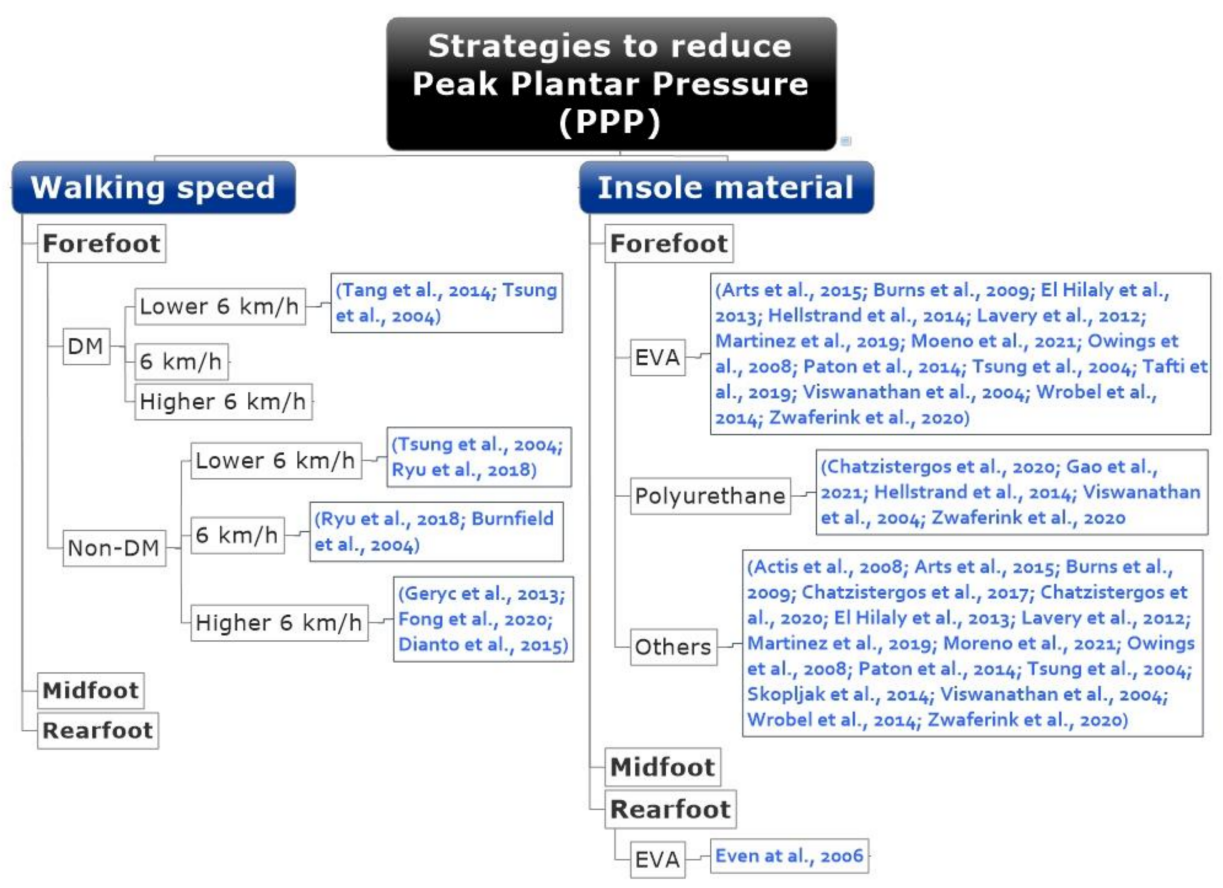

Figure 2. Published paper for reduction peak plantar pressure strategies. DM, diabetes mellitus; non-DM, healthy people; EVA, ethylene-vinyl acetate.

\subsection{The PPP at Different Walking Speeds}

Of the 27 studies, 18 investigated the walking speed at which participants felt comfortable. The walking distance among the subjects was allowed to walk in 8-20 m of length with 15-20 steps and was repeated 2-6 times [48-65]. Three studies did not mention the participants' walking speed, but subjects had to walk to gain the data [66-68]. However, Even-Tzur et al. calculated heel pad pressure using a finite element method and did not perform walking intensities [69] — the insole material used by Even-Tzur et al. had EVA viscoelastic properties [69].

The PPP at different walking speeds in non-DM in five studies was integrated into these results. Ryu et al. asked their subjects to walk at $4 \mathrm{~km} / \mathrm{h}$ and $6 \mathrm{~km} / \mathrm{h}$ [70], while Burnfield et al. set the walking speed at $6 \mathrm{~km} / \mathrm{h}$ [71]. Other walking tests were conducted at $8 \mathrm{~km} / \mathrm{h}$ and $12 \mathrm{~km} / \mathrm{h}$ [72], $10 \mathrm{~km} / \mathrm{h}$ [73], and $12 \mathrm{~km} / \mathrm{h}$ speed [74]. See Table 1 for more detail.

Figure 3 shows the PPP distribution in people with DM and non-DM at different walking speeds $[48,55,70,72-74]$. The mean forefoot PPP at a walking speed of $4 \mathrm{~km} / \mathrm{h}$ was $185 \%$ higher in DM than non-DM people. In addition, the mean PPP under the midfoot and the rearfoot were $135 \%$ and $124 \%$, respectively, greater among DM people. However, among non-DM, we found that the lowest PPP at the three regions was achieved at a walking speed of $6 \mathrm{~km} / \mathrm{h}$. The PPP at $6 \mathrm{~km} / \mathrm{h}$ walking speed was lower than at $4 \mathrm{~km} / \mathrm{h}$, $66 \%$ under the forefoot, $57 \%$ under the midfoot, and $78 \%$ under the rearfoot. On the other hand, the PPP at $8 \mathrm{~km} / \mathrm{h}$ walking speed was remarkably higher than at $4 \mathrm{~km} / \mathrm{h}$ was $236 \%$ under the forefoot, $224 \%$ under the midfoot, and $123 \%$ under the rearfoot. 
Table 1. The peak plantar pressure in preferred walking speed in people with DM and different walking speeds in non-DM people.

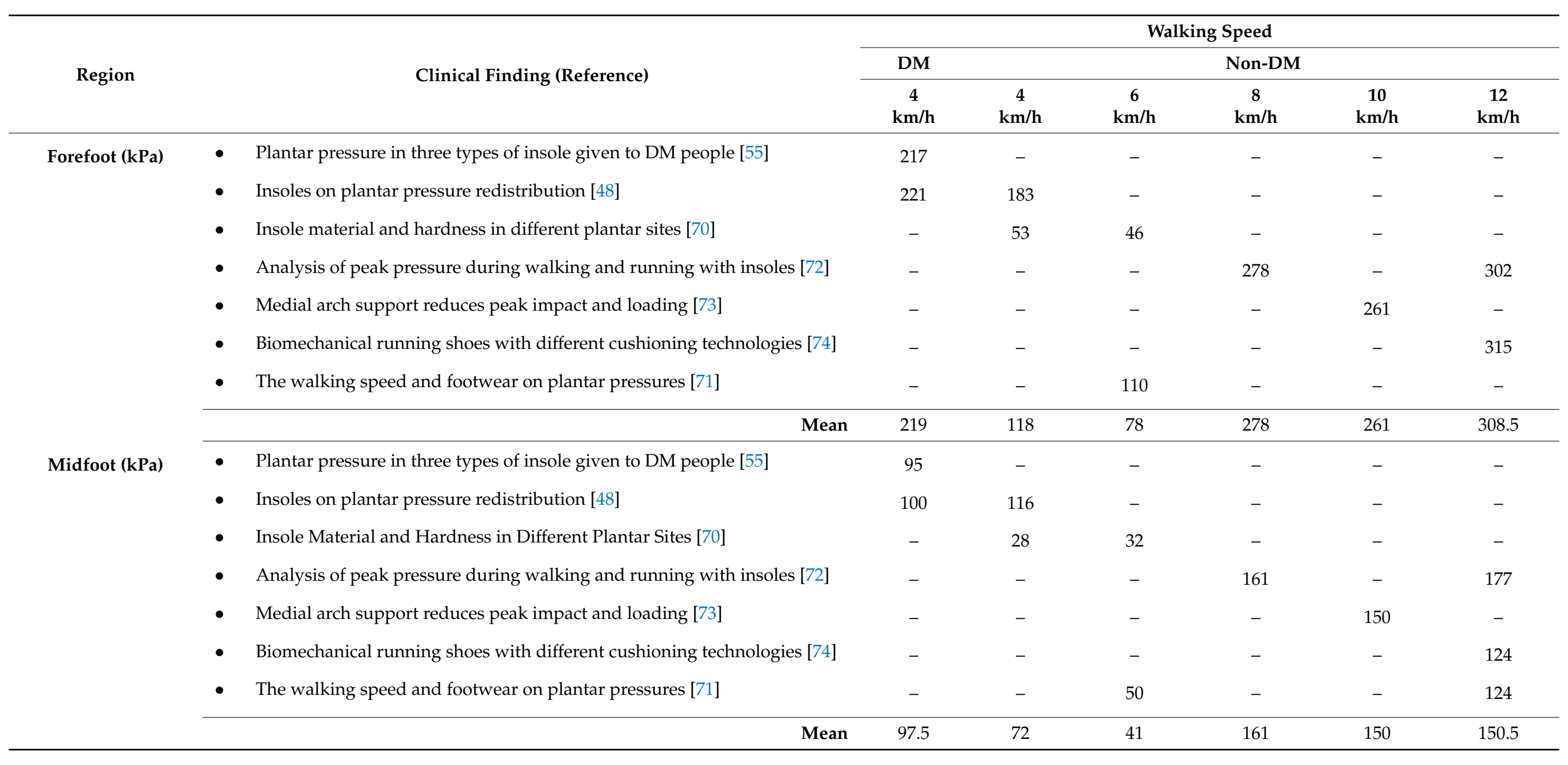


Table 1. Cont.

\begin{tabular}{|c|c|c|c|c|c|c|c|}
\hline \multirow{3}{*}{ Region } & \multirow{3}{*}{ Clinical Finding (Reference) } & \multicolumn{6}{|c|}{ Walking Speed } \\
\hline & & \multirow{2}{*}{$\begin{array}{c}\mathrm{DM} \\
4 \\
\mathrm{~km} / \mathrm{h}\end{array}$} & \multicolumn{5}{|c|}{ Non-DM } \\
\hline & & & $\begin{array}{c}4 \\
\mathrm{~km} / \mathrm{h}\end{array}$ & $\begin{array}{c}6 \\
\mathrm{~km} / \mathrm{h}\end{array}$ & $\begin{array}{c}8 \\
\mathrm{~km} / \mathrm{h}\end{array}$ & $\begin{array}{c}10 \\
\mathrm{~km} / \mathrm{h}\end{array}$ & $\begin{array}{c}12 \\
\mathrm{~km} / \mathrm{h}\end{array}$ \\
\hline \multirow[t]{8}{*}{ Rearfoot (kPa) } & - $\quad$ Plantar pressure in three types of insole given to DM people [55] & 171 & - & - & - & - & - \\
\hline & - Insoles on plantar pressure redistribution [48] & 256 & 240 & - & - & - & - \\
\hline & - Insole Material and Hardness in Different Plantar Sites [70] & - & 104 & 128 & - & - & - \\
\hline & - $\quad$ Analysis of peak pressure during walking and running with insoles [72] & - & - & - & 212 & - & 199 \\
\hline & - $\quad$ Medial arch support reduces peak impact and loading [73] & - & - & - & - & 216 & - \\
\hline & - $\quad$ Biomechanical running shoes with different cushioning technologies [74] & - & - & - & - & - & 303 \\
\hline & - $\quad$ The walking speed and footwear on plantar pressures [71] & - & - & 140 & - & - & 124 \\
\hline & Mean & 213.5 & 172 & 134 & 212 & 216 & 251 \\
\hline
\end{tabular}

Note: DM, diabetes mellitus; $k m / h$, speed units. 


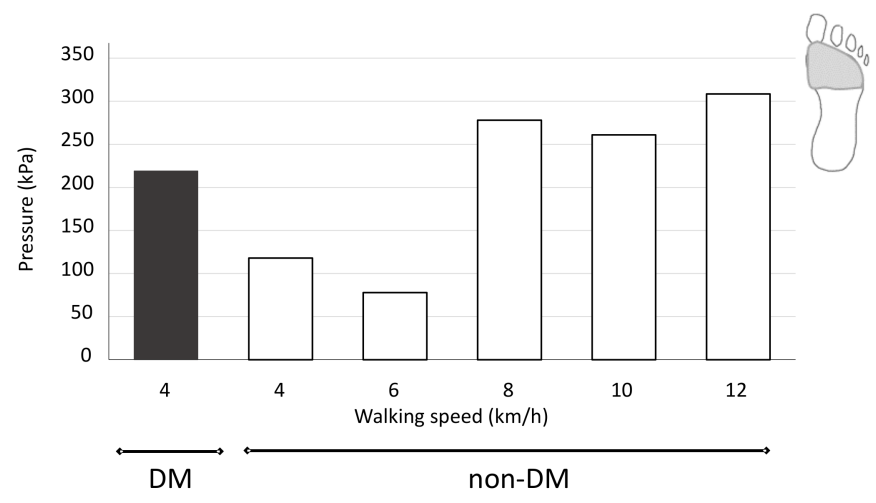

(A)

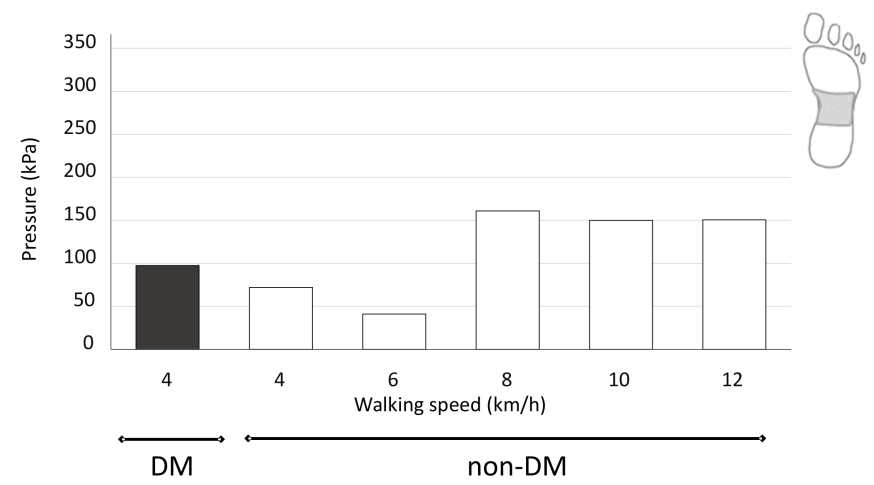

(B)

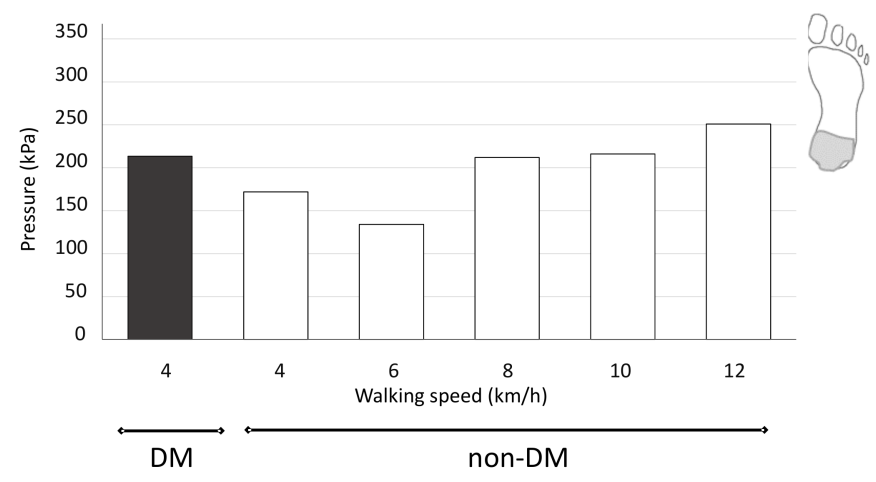

(C)

Figure 3. The PPP at three regions (A) forefoot, (B) midfoot, and (C) rearfoot. The speed was categorized as preferred walking speed in people with DM $(4 \mathrm{~km} / \mathrm{h})$ and five different speeds in non-DM people $(4,6,8,10$, and $12 \mathrm{~km} / \mathrm{h}$, respectively). PPP, peak plantar pressure; DM, diabetes mellitus; non-DM, healthy people.

\subsection{Insole Materials Used in Various Regions}

Figure 4 illustrates the insole materials that have been prescribed in three regions in people with DM [48-57,59-68]. The most common insole materials used at the forefoot regions were EVA $(26 \%)$, followed by Poron $(13 \%)$, Plastazote $(11 \%)$, PU (9\%), PPT (5\%), and others $(36 \%)$. Similarly, insole materials used at the midfoot and rearfoot region were EVA ( $26 \%$ and $27 \%$, respectively), followed by Poron, Plastazote, PU, PPT, and others. 
See the detail of each insole material used for DM people based on the reviewed studies (Tables 2-4). Four studies found that the average PPP reduction using EVA insole material was $38 \%$ on the whole foot and $37 \%$ on the forefoot region (Table 5).

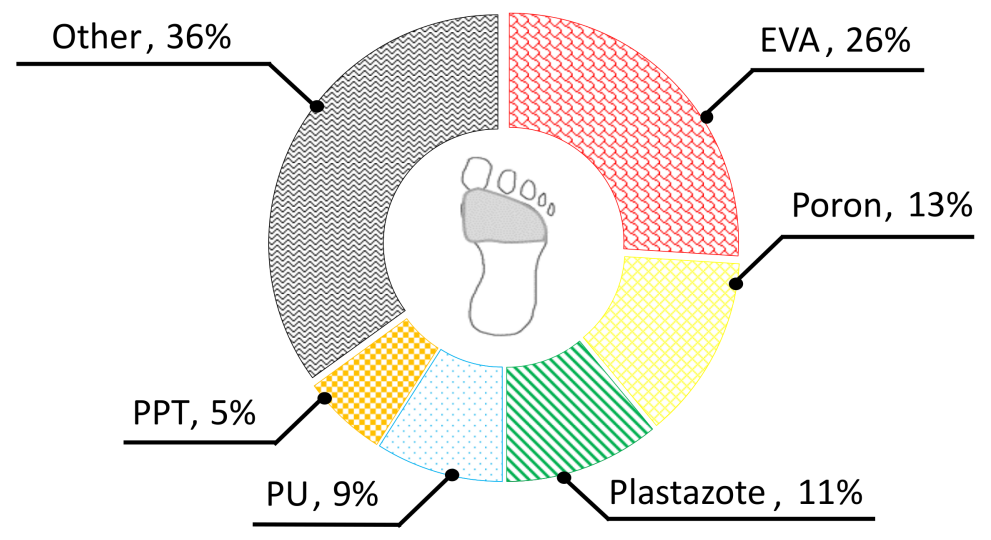

(A)

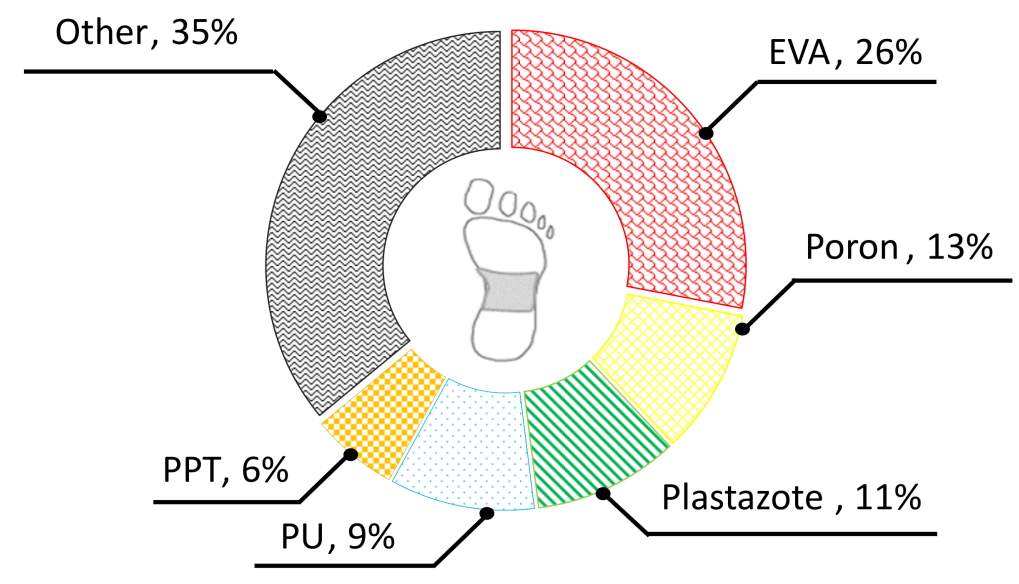

(B)

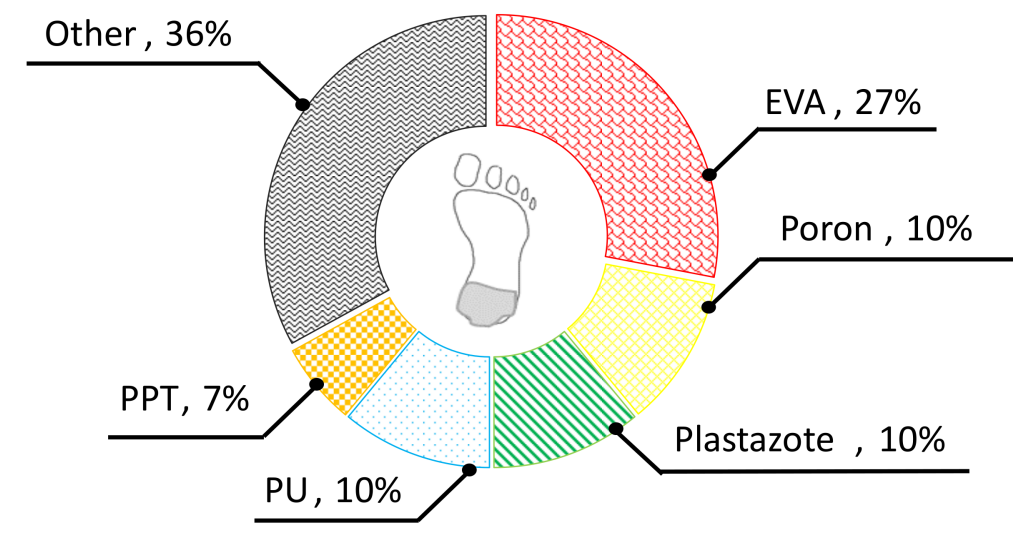

(C)

Figure 4. Published paper used insole material under plantar area: (A) forefoot, (B) midfoot, and (C) rearfoot. EVA, ethylene-vinyl acetate; PU, polyurethane; PPT, Professional Protective Technology. The percentage of insole used in the foot region is based on "summary" divided by the total insole used. The term "other" summarizes 11-13 items that do not represent the most used insole material. 
Table 2. The published paper discussed selected insole materials on the forefoot region.

\begin{tabular}{|c|c|c|c|c|c|c|}
\hline Clinical Finding (Reference) & EVA & Poron & Plastazote & PU & PPT & Other \\
\hline - $\quad$ Multi-plug insole reduces DM PPP [50] & - & 1 & 1 & - & - & - \\
\hline - Footwear provision for diabetic [57] & 1 & - & - & - & - & 2 \\
\hline - Custom orthoses and footwear in diabetic [52] & 1 & - & - & - & - & 5 \\
\hline - Cushioning insole in diabetic footwear [62] & - & 1 & 1 & 1 & - & \\
\hline - Total contact insole in diminishing foot pressures [54] & 1 & 1 & - & - & - & 1 \\
\hline - Diabetic therapeutic footwear on preventing DFUs [64] & - & - & - & 1 & - & \\
\hline $\begin{array}{l}\text { - Plantar pressure in three types of insole given to DM } \\
\text { people [55] }\end{array}$ & 1 & - & - & 1 & - & 2 \\
\hline - Insoles to prevent foot ulceration [66] & 1 & - & - & - & - & 1 \\
\hline - Orthotic insoles for people with diabetes [59] & 1 & 1 & - & - & - & - \\
\hline - Insoles offloading in the diabetic foot [65] & 1 & - & - & - & 1 & - \\
\hline - $\quad$ Cushioned cast reduce foot loading in DM [53] & - & - & - & - & - & 3 \\
\hline - Insole materials influence PPP in DM people [60] & - & - & 1 & - & - & 1 \\
\hline - Custom insoles enhanced pressure relief [51] & 1 & 1 & 1 & - & - & 1 \\
\hline - Insoles for the DM neuropathic foot management [67] & 1 & 1 & - & - & - & - \\
\hline - Insoles on plantar pressure distribution [48] & 1 & 1 & - & - & - & - \\
\hline $\begin{array}{l}\text { - Individual robotic insoles in diagnostic and clinical } \\
\text { application [68] }\end{array}$ & - & - & - & - & - & 1 \\
\hline - Wearing insoles in different densities [61] & 1 & - & - & - & - & - \\
\hline - $\quad$ Different insoles for DM foot [49] & 1 & - & - & 1 & - & 1 \\
\hline - Insoles effect for DM people [56] & 1 & - & 1 & - & 1 & 1 \\
\hline - Footwear for the diabetic foot [63] & 1 & - & 1 & 1 & 1 & 1 \\
\hline Summary & 14 & 7 & 6 & 5 & 3 & 20 \\
\hline Percentage & $26 \%$ & $13 \%$ & $11 \%$ & $9 \%$ & $5 \%$ & $36 \%$ \\
\hline
\end{tabular}

Note: DM, diabetes mellitus; DFUs, diabetic foot ulcers; PPP, peak plantar pressure; EVA, ethylene-vinyl acetate; PU, polyurethane; PPT, Professional Protective Technology.

Table 3. The published paper discussed selected insole materials on the midfoot region.

\begin{tabular}{|c|c|c|c|c|c|c|}
\hline Clinical Finding (Reference) & EVA & Poron & Plastazote & $\overline{\text { PU }}$ & PPT & Other \\
\hline - Footwear provision for diabetic [57] & 1 & - & - & - & - & 2 \\
\hline - Custom orthoses and footwear in diabetic [52] & 1 & - & - & - & - & 5 \\
\hline - Cushioning insole in diabetic footwear [62] & - & 1 & 1 & 1 & - & - \\
\hline - Total contact insole in diminishing foot pressures [54] & 1 & 1 & - & - & - & 1 \\
\hline - Diabetic therapeutic footwear on preventing DFUs [64] & - & - & - & 1 & - & - \\
\hline $\begin{array}{l}\text { - Plantar pressure in three types of insole given to DM } \\
\text { people [55] }\end{array}$ & 1 & - & - & 1 & - & - \\
\hline
\end{tabular}


Table 3. Cont.

\begin{tabular}{|c|c|c|c|c|c|c|}
\hline Clinical Finding (Reference) & EVA & Poron & Plastazote & PU & PPT & Other \\
\hline - Insoles to prevent foot ulceration [66] & 1 & - & - & - & - & 1 \\
\hline - $\quad$ Orthotic insoles for people with diabetes [59] & 1 & - & - & - & - & - \\
\hline - Insoles offloading in the diabetic foot [65] & 1 & - & - & - & 1 & - \\
\hline - $\quad$ Cushioned cast reduce foot loading in DM [53] & - & - & - & - & - & 3 \\
\hline - Insole materials influence PPP in DM people [60] & - & - & 1 & - & - & 2 \\
\hline - Custom insoles enhanced pressure relief [51] & 1 & 1 & 1 & - & - & 1 \\
\hline - Insoles for the DM neuropathic foot management [67] & 1 & 1 & - & - & - & - \\
\hline - Insoles on plantar pressure distribution [48] & 1 & 1 & - & - & - & - \\
\hline $\begin{array}{l}\text { - Individual robotic insoles in diagnostic and clinical } \\
\text { application [68] }\end{array}$ & - & - & - & - & - & 1 \\
\hline - Wearing insoles in different densities [61] & 1 & - & - & - & - & - \\
\hline - $\quad$ Different insoles for DM foot [49] & 1 & - & - & 1 & - & 1 \\
\hline - Insoles effect for DM people [56] & 1 & - & 1 & - & 1 & 1 \\
\hline - $\quad$ Footwear for the diabetic foot [63] & 1 & - & 1 & 1 & 1 & 1 \\
\hline Summary & 14 & 7 & 6 & 5 & 3 & 19 \\
\hline Percentage & $26 \%$ & $13 \%$ & $11 \%$ & $9 \%$ & $6 \%$ & $35 \%$ \\
\hline
\end{tabular}

Note: DM, diabetes mellitus; DFUs, diabetic foot ulcers; PPP, peak plantar pressure; EVA, ethylene-vinyl acetate; PU, polyurethane; PPT, Professional Protective Technology.

Table 4. The published paper discussed selected insole materials on the rearfoot region.

\begin{tabular}{|c|c|c|c|c|c|c|}
\hline Clinical Finding (Reference) & EVA & Poron & Plastazote & PU & PPT & Other \\
\hline - Custom orthoses and footwear in diabetic [52] & 1 & - & - & - & - & 5 \\
\hline - Cushioning insole in diabetic footwear [62] & - & 1 & 1 & 1 & - & - \\
\hline - Total contact insole in diminishing foot pressures [54] & 1 & 1 & - & - & - & 1 \\
\hline - Diabetic therapeutic footwear on preventing DFUs [64] & - & - & - & 1 & - & - \\
\hline $\begin{array}{l}\text { - Plantar pressure in three types of insole given to DM } \\
\text { people [55] }\end{array}$ & 1 & - & - & 1 & - & - \\
\hline - Insoles to prevent foot ulceration [66] & 1 & - & - & - & - & 1 \\
\hline - Orthotic insoles for people with diabetes [59] & 1 & - & - & - & - & - \\
\hline - Insoles offloading in the diabetic foot [65] & 1 & - & - & - & 1 & - \\
\hline - $\quad$ Cushioned cast reduce foot loading in DM [53] & - & - & - & - & - & 3 \\
\hline - Insole materials influence PPP in DM people [60] & - & - & 1 & - & - & 2 \\
\hline - Custom insoles enhanced pressure relief [51] & 1 & 1 & 1 & - & - & 1 \\
\hline - Insoles for the DM neuropathic foot management [67] & 1 & 1 & - & - & - & - \\
\hline - Insoles on plantar pressure distribution [48] & 1 & 1 & - & - & - & - \\
\hline
\end{tabular}


Table 4. Cont.

\begin{tabular}{|c|c|c|c|c|c|c|}
\hline Clinical Finding (Reference) & EVA & Poron & Plastazote & PU & PPT & Other \\
\hline $\begin{array}{l}\text { - Individual robotic insoles in diagnostic and clinical } \\
\text { application [68] }\end{array}$ & - & - & - & - & - & 1 \\
\hline - Wearing insoles in different densities [61] & 1 & - & - & - & - & - \\
\hline - $\quad$ Different insoles for DM foot [49] & 1 & - & - & 1 & - & 1 \\
\hline - Insoles effect for DM people [56] & 1 & - & 1 & - & 1 & 1 \\
\hline - $\quad$ Footwear for the diabetic foot [63] & 1 & - & 1 & 1 & 1 & 1 \\
\hline Summary & 13 & 5 & 5 & 5 & 3 & 17 \\
\hline Percentage & $27 \%$ & $10 \%$ & $10 \%$ & $10 \%$ & $7 \%$ & $36 \%$ \\
\hline
\end{tabular}

Note: DM, diabetes mellitus; DFUs, diabetic foot ulcers; PPP, peak plantar pressure; EVA, ethylene-vinyl acetate; PU, polyurethane; PPT, Professional Protective Technology.

Table 5. EVA insole materials reduce the PPP in the plantar region.

\begin{tabular}{|c|c|c|}
\hline Clinical Finding (Reference) & $\begin{array}{l}\text { Whole Foot } \\
\text { Reduced PPP }\end{array}$ & $\begin{array}{c}\text { Forefoot } \\
\text { Reduced PPP }\end{array}$ \\
\hline - The most common offloading option was the total contact insoles $(16.0 \%)$ [65] & $16 \%$ & - \\
\hline $\begin{array}{l}\text { - The shape-plus-pressure-based insole in the flexible shoe achieved superior } \\
\text { unloading (32\%), compared with the two shape-based insoles [51] }\end{array}$ & - & $32 \%$ \\
\hline $\begin{array}{l}\text { - Patients who were using therapeutic footwear showed lower foot pressure } \\
\text { compared to non-therapeutic footwear [49] }\end{array}$ & $60 \%$ & - \\
\hline $\begin{array}{l}\text { - All data-driven footwear conditions significantly reduced metatarsal head peak } \\
\text { pressure, compared with the non-therapeutic shoe [63] }\end{array}$ & - & $42 \%$ \\
\hline Mean reduced PPP & $38 \%$ & $37 \%$ \\
\hline
\end{tabular}

Note: PPP, peak plantar pressure.

\subsection{Insole Mechanical Properties}

Chatzistergos et al. used polyurethane foam as an insole with a mechanical stiffness ranging from $35 \mathrm{kPa}$ to $350 \mathrm{kPa}$, and from 2 to 20 Shore $\mathrm{A}$. The pressure reduction was around 5-29\% in walking speed ranging between $4.3 \mathrm{~km} / \mathrm{h}$ and $5.8 \mathrm{~km} / \mathrm{h}$ (Figure 5A) [58]. The insole material was 3D printed in thermoplastic polyurethane conducted by Chatzistergos et al. (2020), formed at different densities (10-20\%), with the stiffness ranging from $110 \mathrm{kPa}$ to $350 \mathrm{kPa}$ with pressure reduction ranging from $20 \%$ to $38 \%$ at selected walking speeds (Figure 5B) [62]. Even et al. used EVA in a finite element study to predict a reduction of $2 \mathrm{kPa}$ with $10 \%$ thickness and $8 \mathrm{kPa}$ with $50 \%$ thickness on peak heel pad stress compared to without EVA. The peak heel pad stress was predicted to be reduced by $13.5 \mathrm{kPa}$ (125\% of insole elastic modulus) and $13 \mathrm{kPa}(150 \%$ of insole elastic modulus) (Figure 5C) [69]. Table 6 describes the material of the insole based on their character and function used in plantar regions. 


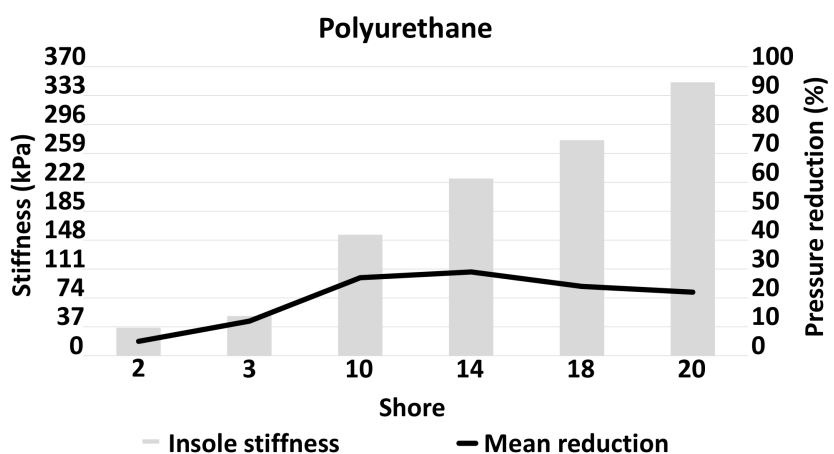

(A)

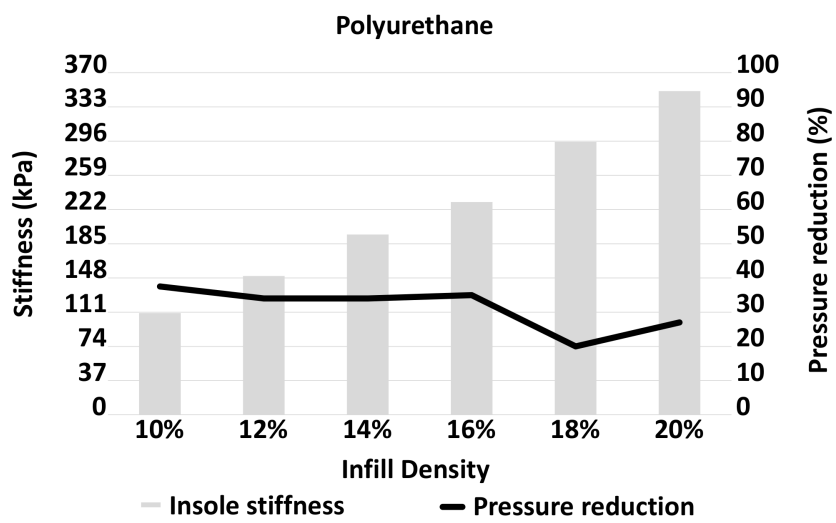

(B)

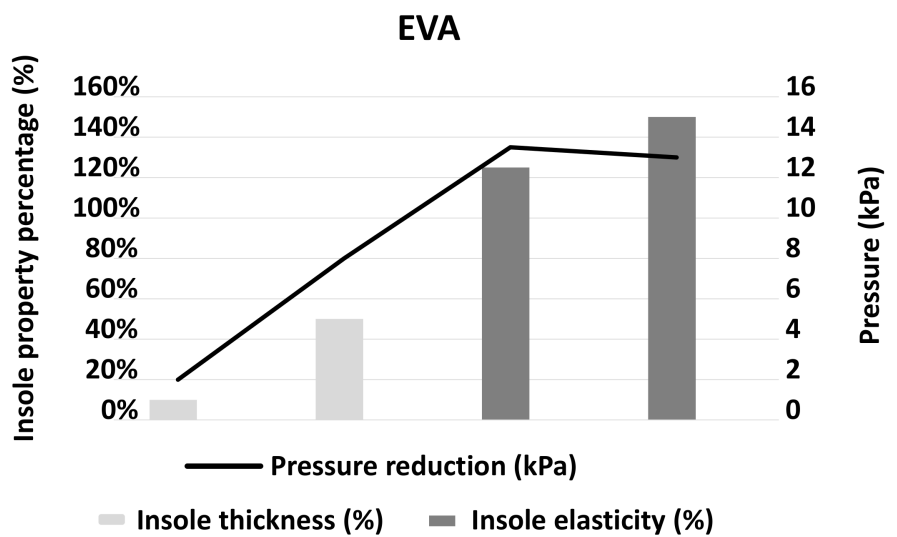

(C)

Figure 5. Pressure reduction in different insole material properties: (A) PU foam, (B) 3D-printed thermoplastic PU, and (C) EVA. PU, polyurethane; 3D, three dimensions; EVA, ethylene-vinyl acetate. 
Table 6. Insole materials based on their character and function used in plantar regions.




Table 6. Cont.

\begin{tabular}{|c|c|c|c|c|c|c|}
\hline \multirow{2}{*}{ Material Form } & \multirow{2}{*}{ Combination Material } & \multicolumn{2}{|c|}{ Character } & \multirow{2}{*}{ Plantar Region } & \multirow{2}{*}{ Region Function } & \multirow{2}{*}{ Reference } \\
\hline & & Thickness & Shore & & & \\
\hline \multicolumn{7}{|l|}{ Poron } \\
\hline Soft & EVA, flexible cotton & $\begin{array}{l}\text { Poron }(4 \mathrm{~mm}) \\
\text { EVA }(4 \mathrm{~mm}) \\
\text { Flexi cotton }(1 \mathrm{~mm})\end{array}$ & $\begin{array}{l}(\mathrm{n} / \mathrm{a}) \\
(\mathrm{n} / \mathrm{a}) \\
(\mathrm{n} / \mathrm{a})\end{array}$ & MTH, RF & Decrease pressure & {$[54]$} \\
\hline Soft & EVA & $\begin{array}{l}\text { Poron }(3 \mathrm{~mm}) \\
\text { EVA }(5 \mathrm{~mm})\end{array}$ & $\begin{array}{l}20 \text { Shore A } \\
50 \text { Shore A }\end{array}$ & MTH & Reduce MTH pressure & [59] \\
\hline \multicolumn{7}{|l|}{ Plastazote } \\
\hline Total contact, elastic & $(\mathrm{n} / \mathrm{a})$ & $10 \mathrm{~mm}$ & 35 Shore A & MTH & $\begin{array}{l}\text { Redistribute pressure under } \\
\text { MTH. }\end{array}$ & {$[50]$} \\
\hline Elastic & Microcellular rubber & $\begin{array}{l}\text { Plastazote }(8 \mathrm{~mm}) \\
\text { Microcellular rubber }(10 \\
\mathrm{mm})\end{array}$ & $\begin{array}{l}25 \text { Shore A } \\
70 \text { Shore A }\end{array}$ & WF & Reduce pressure & {$[60]$} \\
\hline Soft & PPT & $\begin{array}{l}\text { Plastazote }(n / a) \\
\operatorname{PPT}(n / a)\end{array}$ & $\begin{array}{l}(\mathrm{n} / \mathrm{a}) \\
(\mathrm{n} / \mathrm{a})\end{array}$ & WF & $\begin{array}{l}\text { Standard insole, pressure } \\
\text { resistance }\end{array}$ & {$[56]$} \\
\hline Soft pad & PPT & $\begin{array}{l}\text { Plastazote }(3 \mathrm{~mm}) \\
\text { PPT }(3 \mathrm{~mm})\end{array}$ & $\begin{array}{l}25 \text { Shore A } \\
(\mathrm{n} / \mathrm{a})\end{array}$ & MTH & Reduce MTH pressure 30\%) & [63] \\
\hline \multicolumn{7}{|l|}{ PU } \\
\hline Lightweight, flexible & $(\mathrm{n} / \mathrm{a})$ & $5 \mathrm{~mm}$ & $(\mathrm{n} / \mathrm{a})$ & WF & Reduce the PPP & [49] \\
\hline Molded, flexible, lightweight & $(\mathrm{n} / \mathrm{a})$ & $6 \mathrm{~mm}$ & $(\mathrm{n} / \mathrm{a})$ & WF & Pressure reduction & [49] \\
\hline Foam and vibrator & $\begin{array}{l}\text { vibration devices, merino } \\
\text { wool }\end{array}$ & PU 6-12 mm & $(\mathrm{n} / \mathrm{a})$ & $\mathrm{FF}, \mathrm{A}, \mathrm{RF}$ & $\begin{array}{l}\text { Reduce the recurrence ulcer } \\
\text { (redistribute the pressure) }\end{array}$ & {$[64]$} \\
\hline Soft & $(\mathrm{n} / \mathrm{a})$ & $(\mathrm{n} / \mathrm{a})$ & $(\mathrm{n} / \mathrm{a})$ & WF & Redistribute the pressure & [63] \\
\hline Cushion & $(\mathrm{n} / \mathrm{a})$ & $10 \mathrm{~mm}$ & $(\mathrm{n} / \mathrm{a})$ & $\mathrm{WF}$ & $\begin{array}{l}\text { Reduce PPP with different } \\
\text { density }\end{array}$ & [62] \\
\hline Various stiffness & $(\mathrm{n} / \mathrm{a})$ & $(\mathrm{n} / \mathrm{a})$ & $(\mathrm{n} / \mathrm{a})$ & WF & $\begin{array}{l}\text { Stiffness optimizations } \\
\text { reduce PPP }\end{array}$ & {$[58]$} \\
\hline \multicolumn{7}{|l|}{ Other } \\
\hline $\begin{array}{l}\text { Polyethylene foam } \\
\text { (molded, total contact, flexible) }\end{array}$ & $(\mathrm{n} / \mathrm{a})$ & $4 \mathrm{~mm}$ & $(\mathrm{n} / \mathrm{a})$ & $\mathrm{WF}$ & Retain its shape & {$[50]$} \\
\hline $\begin{array}{l}\text { Cork } \\
\text { (cast, elastic) }\end{array}$ & EVA, Plastazote & $\begin{array}{l}\text { Cork }(n / a) \\
\text { EVA (n/a) } \\
\text { Plastazote (n/a) }\end{array}$ & $(\mathrm{n} / \mathrm{a})$ & MTH & Pressure reduction & [57] \\
\hline
\end{tabular}


Table 6. Cont.

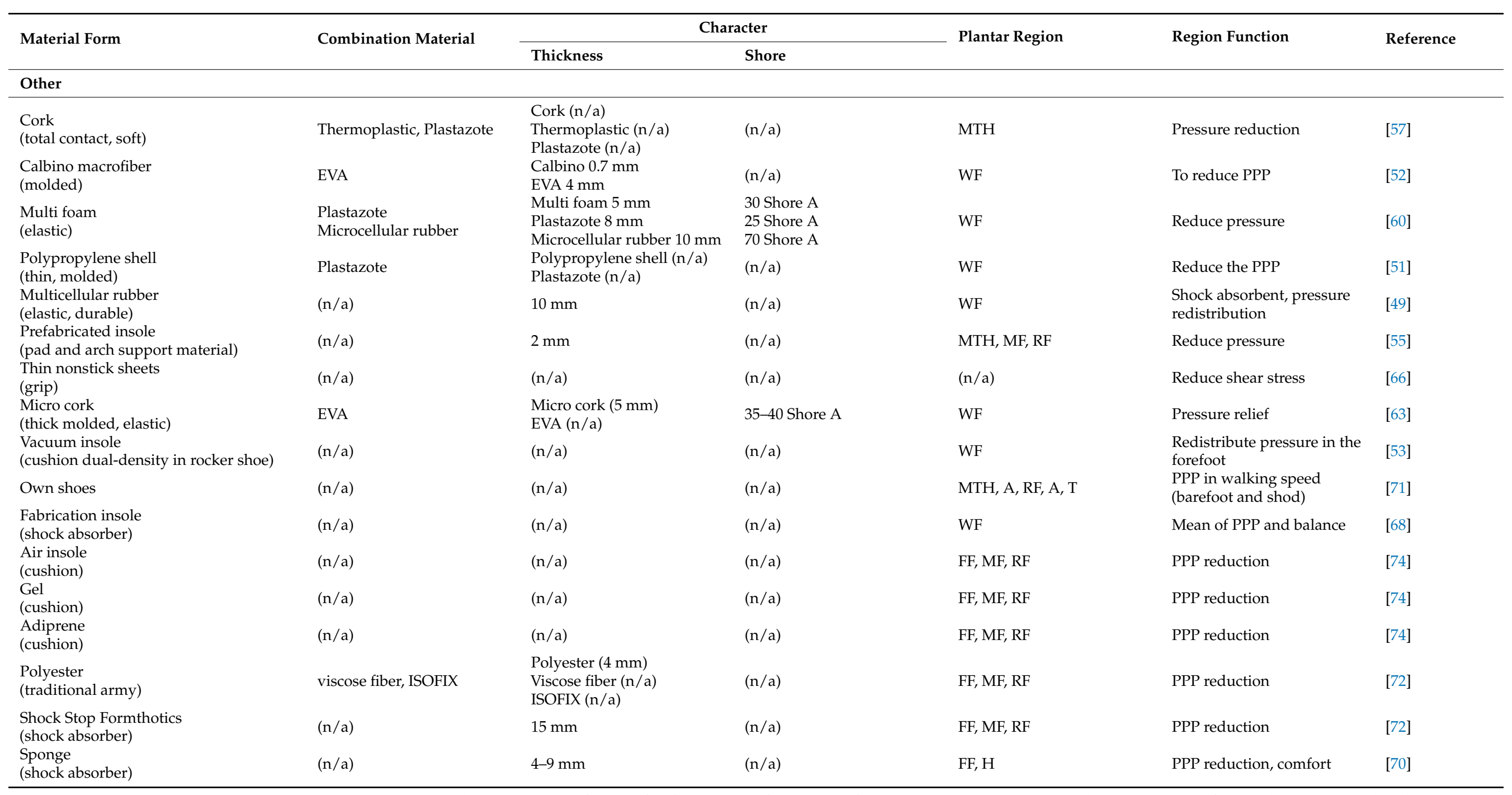


polyurethane; $\mathrm{n} / \mathrm{a}$, not applicable. 


\section{Discussion}

This study analyzed the available data on the PPP effect at different walking speeds and various insole materials in healthy people and people with DM. Our results have important implications that the appropriate walking speed for healthy people was around $6 \mathrm{~km} / \mathrm{h}$. In contrast, an appropriate walking speed for DM people was around $4 \mathrm{~km} / \mathrm{h}$. Moreover, the forefoot pressure at $4 \mathrm{~km} / \mathrm{h}$ walking speed in people with DM was nearly two times higher than that for non-DM people. The EVA was the most often used insole material for walking at the forefoot region (26\%). EVA reduced the PPP by $37 \%$ on the DM forefoot region.

Our results showed that $6 \mathrm{~km} / \mathrm{h}$ was the appropriate walking speed for non-DM, with the lowest PPP in the forefoot, midfoot, and rearfoot regions (Figure 2). McClymont et al. demonstrated that when walking faster, the mean square error, one of the variability metrics of plantar pressures, increased considerably [75]. Elevated plantar pressures may accumulate tension abnormally over the plantar soft tissue [76]. Therefore, to reach the lowest PPP, DM people and non-DM may have different suitable walking speeds [31,32,77]. Non-DM appropriate walking speed was closely correlated with the neutral subtalar joint position, neither pronated nor supinated, which may reduce PPP [78]. Moreover, a walking speed above $6 \mathrm{~km} / \mathrm{h}$ in non-DM has a high PPP on the forefoot region (Figure 2). Martinez et al. stated that ankle joint position changed into high pronation during faster walking [79]. The transformation into a pronated position at faster walking speeds might be due to muscle fatigue-inducing high pressure under the forefoot $[28,29]$. In addition, a walking speed of less than $6 \mathrm{~km} / \mathrm{h}$ showed increased PPP on the heel (Figure 2). One reason why the rearfoot region has a high PPP may be founded on the increased contact time of slow walking due to severe internal distortion between bone and soft tissue [80].

The study concluded that the forefoot PPP at $4 \mathrm{~km} / \mathrm{h}$ walking speed was nearly two times (185\%) higher in DM people than non-DM people (Figure 2). The high PPP at $4 \mathrm{~km} / \mathrm{h}$ walking speed may have three reasons: increased contact time, ankle joint stiffness, and soft tissue stiffness. First, DM people lose ankle movement perception, owing to increasing step time to walk carefully to keep their balance at $4 \mathrm{~km} / \mathrm{h}$ walking speed $[27,81]$. Hence, DM people decreased their step length, gained slower walking speeds, and had higher PPP in the forefoot region than non-DM [27,32]. Second, high PPP at $4 \mathrm{~km} / \mathrm{h}$ walking speed on DM people was due to ankle joint stiffness (severe DM; $0.236 \mathrm{~N} \cdot \mathrm{m} / \mathrm{deg}$ compared with normal DM: $-0.113 \mathrm{~N} \cdot \mathrm{m} / \mathrm{deg}$ ) [82]. Ankle plantar flexor (equinus) in DM becomes contracture, produced by stiff tissue causes the heel to rise earlier than normal, employing higher pressure on the forefoot [83]. Third, DM people have high PPP at $4 \mathrm{~km} / \mathrm{h}$ walking speed due to tissue stiffness. Sun et al. demonstrated that soft tissue stiffness in the forefoot of people with DM was around 1.5 times higher (155\%) than non-DM [84]. Increases in diabetic soft tissue stiffness may be attributed to the accumulation of cross-linked collagen molecules, which are abundant in soft tissue [85]. Electron microscopy shows evidence of regular collagen alignment loss, increased collagen fibril density, and increased fibril adhesion in patients with DM [86,87].

This study revealed that the most commonly used insole material in the forefoot was EVA $(26 \%)$. EVA decreased the forefoot pressure by about $37 \%$ during walking in people with DM (Figure 3 and Table 5). The EVA insole, a foam-based material that provides high resilience, is excellent for reusing mechanical energy at the forefoot on the push-off phase during walking $[44,88,89]$. The typical rebound resilience of polyethylene foam ranged from about 30\% to $40 \%$ [90]. In addition, the cushioning function of the insole provides extra resilience to the EVA insole material. Kwon et al. stated that when the resilience of EVA reached $63 \%$, the insole was softer compared with $17 \%$ that was stiffer [91]. Furthermore, the Australian Diabetic Association suggested that DM people wear soft but sufficiently resilient insole because it redistributes plantar pressure and increases contact time between the foot and insole [22]. It means that EVA materials might be excellent in reusing mechanical energy by adjusting greater resilience [92]. 
Aside from EVA, PU is a good insole material for pressure reduction in the forefoot [43]. This study discovered that the mechanical properties of the PU insole have almost the same PPP reduction as EVA (37\%) (Figure 4B). The mechanical properties of the PU insole reduced the pressure by around $30 \%$ at 14 Shore $\mathrm{A}$ and about $40 \%$ in $10-16 \% 3 \mathrm{D}$ printing infill density. Cushioning and stiffness optimization of the PU insole has been approved for decreasing the PPP in the forefoot $[58,62]$. Some researchers argued that PU has some advantages in its mechanical properties $[93,94]$. Nonetheless, PU is more expensive than EVA $[93,95,96]$. Thus, PU could be the multi-insole in part of the plantar region combined with another insole material [41,97].

This study has two limitations. First, our study was limited to discussing EVA and PU in pressure reduction but not in Plastazote and Poron as the second and third most commonly used insole materials. Only a few researchers examined Plastazote and Poron because they need longer walking duration to induce pressure reduction. For example, after a month of use, a single Plastazote has the pressure reduction result [98], and Poron has the pressure reduction after 50,000 steps [43]. If four insole materials are compared in the same procedure, the results may show different PPP reductions. Thus, the walking duration effect to induce pressure reduction should be conducted in further studies. Second, our study focused on the three regions of PPP reduction in walking speeds and insole materials-forefoot, midfoot, and rearfoot. Since the first and second metatarsal heads in the forefoot medial region change pronated positions, alongside the three regions in this study, DFUs may occur in other smaller regions. Due to other smaller regions being at high risk for DFUs, future work may be arranged to investigate the other foot regions such as the first toe.

\section{Conclusions}

This study is essential in better understanding the insole materials that improve PPP reduction in various walking speeds in people with DM. We established that the appropriate walking speed for non-DM people is $6 \mathrm{~km} / \mathrm{h}$. Four $\mathrm{km} / \mathrm{h}$ is the appropriate walking speed for DM people, with $185 \%$ forefoot pressure higher than non-DM. The EVA is the most commonly used material with $37 \%$ forefoot pressure reduction. Therefore, the clinician may recommend people with DM to walk at an appropriate speed and wear proper insole material to minimize the DFUs risk.

Author Contributions: Conceptualization, F.H. and C.-W.L.; methodology, F.H. and C.-W.L.; validation, B.-Y.L., Y.P. and K.-H.L.; investigation, F.H. and C.-W.L.; writing-original draft preparation, F.H. and C.-W.L.; writing—review and editing, Y.P., V.B.H.A., B.-Y.L. and Y.-K.J.; supervision, Y.-K.J. and C.-W.L.; funding acquisition, C.-W.L. All authors have read and agreed to the published version of the manuscript.

Funding: This study was funded by the Ministry of Science and Technology of the Republic of China (MOST-110-2221-E-468-005, MOST-110-2813-C-468-134-E, and MOST-110-2637-E-241-002). The funding agency did not have any involvement in data collection, data analysis, and data interpretation.

Institutional Review Board Statement: Not applicable.

Informed Consent Statement: Informed consent was obtained from all subjects involved in the study.

Data Availability Statement: The dataset used for analysis during the current study are available from the corresponding author on reasonable request.

Acknowledgments: The authors wish to express gratitude to Ferry Fadzlul Rahman for the assistance.

Conflicts of Interest: The authors declare that they have no known competing financial interests or personal relationships that could have appeared to influence the work reported in this paper. 


\section{References}

1. Bus, S.A.; van Netten, J.J.; Lavery, L.A.; Monteiro-Soares, M.; Rasmussen, A.; Jubiz, Y.; Price, P.E.; International Working Group on the Diabetic Foot. IWGDF guidance on the prevention of foot ulcers in at-risk patients with diabetes. Diabetes-Metab. Res. Rev. 2016, 32, 16-24. [CrossRef]

2. Saeedi, P.; Petersohn, I.; Salpea, P.; Malanda, B.; Karuranga, S.; Unwin, N.; Colagiuri, S.; Guariguata, L.; Motala, A.A.; Ogurtsova, K.; et al. Global and regional diabetes prevalence estimates for 2019 and projections for 2030 and 2045: Results from the International Diabetes Federation Diabetes Atlas, 9th edition. Diabetes Res. Clin. Pract. 2019, 157, 107843. [CrossRef] [PubMed]

3. Paton, J.S.; Stenhouse, E.A.; Bruce, G.; Zahra, D.; Jones, R.B. A comparison of customised and prefabricated insoles to reduce risk factors for neuropathic diabetic foot ulceration: A participant-blinded randomised controlled trial. J. Foot Ankle Res. $2012,5,31$. [CrossRef] [PubMed]

4. Healy, A.; Dunning, D.; Chockalingam, N. Effect of insole material on plantar pressure. Footwear Sci. 2011, 3, S69-S70. [CrossRef]

5. Bus, S.A.; Haspels, R.; Busch-Westbroek, T.E. Evaluation and optimization of therapeutic footwear for neuropathic diabetic foot patients using in-shoe plantar pressure analysis. Diabetes Care 2011, 34, 1595-1600. [CrossRef] [PubMed]

6. Teoh, J.C.; Lee, T. Identification of potential plantar ulceration among diabetes patients using plantar soft tissue stiffness. J. Mech. Behav. Biomed. Mater. 2020, 103, 103567. [CrossRef] [PubMed]

7. Rice, J.B.; Desai, U.; Cummings, A.K.; Birnbaum, H.G.; Skornicki, M.; Parsons, N.B. Burden of diabetic foot ulcers for medicare and private insurers. Diabetes Care 2014, 37, 651-658. [CrossRef]

8. Colberg, S.R.; Grieco, C.R. Exercise in the treatment and prevention of diabetes. Curr. Sports Med. Rep. 2009, 8, 169-175. [CrossRef] [PubMed]

9. ADA. Standards of Care in Diabetes-2020; American Diabetes Association: Danvers, MA, USA, 2020; Volume 43, p. 224.

10. Boulé, N.G.; Kenny, G.P.; Haddad, E.; Wells, G.A.; Sigal, R.J. Meta-analysis of the effect of structured exercise training on cardiorespiratory fitness in Type 2 diabetes mellitus. Diabetologia 2003, 46, 1071-1081.

11. Chen, L.; Pei, J.-H.; Kuang, J.; Chen, H.-M.; Chen, Z.; Li, Z.-W.; Yang, H.-Z. Effect of lifestyle intervention in patients with type 2 diabetes: A meta-analysis. Metabolism 2015, 64, 338-347. [CrossRef]

12. Hu, F.B.; Stampfer, M.J.; Solomon, C.; Liu, S.; Colditz, G.A.; Speizer, F.E.; Willett, W.C.; Manson, J.E. Physical activity and risk for cardiovascular events in diabetic women. Ann. Intern. Med. 2001, 134, 96-105. [CrossRef] [PubMed]

13. Colberg, S.R.; Sigal, R.J.; Yardley, J.E.; Riddell, M.C.; Dunstan, D.W.; Dempsey, P.C.; Horton, E.S.; Castorino, K.; Tate, D.F. Physical activity/exercise and diabetes: A position statement of the American Diabetes Association. Diabetes Care 2016, 39, $2065-2079$. [CrossRef] [PubMed]

14. Gordon, C.D.; Wilks, R.; McCaw-Binns, A. Effect of aerobic exercise (walking) training on functional status and health-related quality of life in chronic stroke survivors: A randomized controlled trial. Stroke 2013, 44, 1179-1181. [CrossRef]

15. Brooks, C. Adult physical activity behavior: A trend analysis. J. Clin. Epidemiol. 1988, 41, 385-392. [CrossRef]

16. Siegel, P.Z.; Brackbill, R.M.; Heath, G.W. The epidemiology of walking for exercise: Implications for promoting activity among sedentary groups. Am. J. Public Health 1995, 85, 706-710. [CrossRef] [PubMed]

17. Stephens, T.; Jacobs, D.R., Jr.; White, C.C. A descriptive epidemiology of leisure-time physical activity. Public Health Rep. 1985, $100,147$.

18. Mak, A.F.; Zhang, M.; Tam, E.W. Biomechanics of pressure ulcer in body tissues interacting with external forces during locomotion. Annu. Rev. Biomed. Eng. 2010, 12, 29-53. [CrossRef]

19. Patry, J.; Belley, R.; Côté, M.; Chateau-Degat, M.-L. Plantar pressures, plantar forces, and their influence on the pathogenesis of diabetic foot ulcers: A review. J. Am. Podiatr. Med. Assoc. 2013, 103, 322-332. [CrossRef]

20. Wu, F.-L.; Wang, W.T.-J.; Liao, F.; Elliott, J.; Jain, S.; Jan, Y.-K. Effects of walking speeds and durations on plantar skin blood flow responses. Microvasc. Res. 2020, 128, 103936. [CrossRef]

21. Speed, G.; Harris, K.; Keegel, T. The effect of cushioning materials on musculoskeletal discomfort and fatigue during prolonged standing at work: A systematic review. Appl. Ergon. 2018, 70, 300-314. [CrossRef] [PubMed]

22. van Netten, J.J.; Lazzarini, P.A.; Armstrong, D.G.; Bus, S.A.; Fitridge, R.; Harding, K.; Kinnear, E.; Malone, M.; Menz, H.B.; Perrin, B.M. Diabetic Foot Australia guideline on footwear for people with diabetes. J. Foot Ankle Res. 2018, 11, 1-14. [CrossRef] [PubMed]

23. Zulkifli, S.S.; Loh, W.P. A state-of-the-art review of foot pressure. Foot Ankle Surg. 2020, 26, 25-32. [CrossRef]

24. Lung, C.-W.; Wu, F.-L.; Zhang, K.; Liau, B.-Y.; Townsend, R.; Jan, Y.-K. Using Elastographic Ultrasound to Assess Plantar Tissue Stiffness after Walking at Different Speeds and Durations. Appl. Sci. 2020, 10, 7498. [CrossRef]

25. Chen, H.-C.; Liau, B.-Y.; Lin, C.-Y.; Akbari, V.B.H.; Lung, C.-W.; Jan, Y.-K. Estimation of Various Walking Intensities Based on Wearable Plantar Pressure Sensors Using Artificial Neural Networks. Sensors 2021, 21, 6513. [CrossRef]

26. Paul, S.; Kumar, D.P.; Siva, B. Material Analysis for Therapeutic Insoles. 2020. Available online: https://www.researchgate.net/ publication/346690915_Material_Analysis_for_Therapeutic_Insoles (accessed on 8 December 2021).

27. Segal, A.; Rohr, E.; Orendurff, M.; Shofer, J.; O’Brien, M.; Sangeorzan, B. The Effect of Walking Speed on Peak Plantar Pressure. Foot Ankle Int. 2004, 25, 926-933. [CrossRef]

28. Weist, R.; Eils, E.; Rosenbaum, D. The influence of muscle fatigue on electromyogram and plantar pressure patterns as an explanation for the incidence of metatarsal stress fractures. Am. J. Sports Med. 2004, 32, 1893-1898. [CrossRef] [PubMed]

29. Bisiaux, M.; Moretto, P. The effects of fatigue on plantar pressure distribution in walking. Gait Posture 2008, 28, 693-698. [CrossRef] 
30. Caravaggi, P.; Leardini, A.; Giacomozzi, C. Multiple linear regression approach for the analysis of the relationships between joints mobility and regional pressure-based parameters in the normal-arched foot. J. Biomech. 2016, 49, 3485-3491. [CrossRef] [PubMed]

31. Johnson, S.T.; Tudor-Locke, C.; McCargar, L.J.; Bell, R.C. Measuring habitual walking speed of people with type 2 diabetes: Are they meeting recommendations? Diabetes Care 2005, 28, 1503-1504. [CrossRef]

32. Ko, M.; Hughes, L.; Lewis, H. Walking speed and peak plantar pressure distribution during barefoot walking in persons with diabetes. Physiother. Res. Int. 2012, 17, 29-35. [CrossRef]

33. Chang, B.C.; Liu, D.H.; Chang, J.L.; Lee, S.H.; Wang, J.Y. Plantar pressure analysis of accommodative insole in older people with metatarsalgia. Gait Posture 2014, 39, 449-454. [CrossRef]

34. Lo, W.; Yick, K.L.; Ng, S.; Yip, J. Numerical simulation of orthotic insole deformation for diabetic foot. J. Fiber Bioeng. Inform. 2015, 8, 401-411.

35. Nunns, M.P.I.; Dixon, S.J.; Clarke, J.; Carre, M. Boot-insole effects on comfort and plantar loading at the heel and fifth metatarsal during running and turning in soccer. J. Sports Sci. 2016, 34, 730-737. [CrossRef]

36. Praet, S.F.E.; Louwerens, J.-W.K. The influence of shoe design on plantar pressures in neuropathic feet. Diabetes Care 2003, 26, 441-445. [CrossRef] [PubMed]

37. Hall, M.; Shurr, D.G.; Zimmerman, M.B.; Saltzman, C.L. Plantar foot surface temperatures with use of insoles. Iowa Orthop. J. 2004, 24, 72-75.

38. Collings, R.; Freeman, J.A.; Latour, J.; Vickery, P.J.; Glasser, S.; Lepesis, V.; Enki, D.; Paton, J. INSoles To Ease Pressure (INSTEP) Study: A multicentre, randomised controlled feasibility study to compare the effectiveness of a novel instant optimised insole with a standard insole for people with diabetic neuropathy: A study protocol. BMJ Open 2019, 9, e029185. [CrossRef] [PubMed]

39. Lobmann, R.; Kayser, R.; Kasten, G.; Kasten, U.; Kluge, K.; Neumann, W.; Lehnert, H. Effects of preventative footwear on foot pressure as determined by pedobarography in diabetic patients: A prospective study. Diabet. Med. 2001, 18, 314-319. [CrossRef]

40. Lin, T.L.; Sheen, H.M.; Chung, C.T.; Yang, S.W.; Lin, S.Y.; Luo, H.J.; Chen, C.Y.; Chan, I.C.; Shih, H.S.; Sheu, W.H. The effect of removing plugs and adding arch support to foam based insoles on plantar pressures in people with diabetic peripheral neuropathy. J. Foot Ankle Res. 2013, 6, 29. [CrossRef]

41. Shakouri, E.; Mossayebi, A.; Saraeian, P. Fabrication of medical footwear for suitable distribution of stress and strain and reduction of plantar pressure by numerical and experimental approaches. Proc. Inst. Mech. Eng. Part H J. Eng. Med. 2019, 233, 1051-1063. [CrossRef] [PubMed]

42. Kästenbauer, T.; Sokol, G.; Auinger, M.; Irsigler, K. Running shoes for relief of plantar pressure in diabetic patients. Diabet. Med. 1998, 15, 518-522. [CrossRef]

43. Rogers, K.; Otter, S.; Birch, I. The effect of PORON and Plastazote insoles on forefoot plantar pressures. Br. J. Podiatry 2006, 9, 111-114.

44. Ahmed, S.; Barwick, A.; Butterworth, P.; Nancarrow, S. Footwear and insole design features that reduce neuropathic plantar forefoot ulcer risk in people with diabetes: A systematic literature review. J. Foot Ankle Res. 2020, 13, 1-13. [CrossRef]

45. Mamizadeh, M.; Tardeh, Z.; Azami, M. The association between psoriasis and diabetes mellitus: A systematic review and meta-analysis. Diabetes Metab. Syndr. Clin. Res. Rev. 2019, 13, 1405-1412. [CrossRef]

46. Widyasari, V.; Rahman, F.F.; Lin, K.-H.; Wang, J.-Y. The Effectiveness of Health Services Delivered by Community Health Workers on Outcomes Related to Non-Communicable Dis-eases among Elderly People in Rural Areas: A Systematic Review. Iran. J. Public Health 2021, 50, 1088-1096.

47. Rahman, F.F.; Widyasari, V.; Pranata, M.A.E.; Lin, K.-H. Sleep Disorder and its Psychological Impact on Retired Elders: A Systematic Review. Rev. Argent. Clín. Psicol. 2020, 29, 2002-2015.

48. San Tsung, B.Y.; Zhang, M.; Arthur Fuk Tat, M.; Margaret Wan Nar, W. Effectiveness of insoles on plantar pressure redistribution. J. Rehabil. Res. Dev. 2004, 41, 767-774. [CrossRef] [PubMed]

49. Viswanathan, V.; Madhavan, S.; Gnanasundaram, S.; Gopalakrishna, G.; Das, B.N.; Rajasekar, S.; Ramachandran, A. Effectiveness of different types of footwear insoles for the diabetic neuropathic foot: A follow-up study. Diabetes Care 2004, 27, $474-477$. [CrossRef]

50. Actis, R.L.; Ventura, L.B.; Lott, D.J.; Smith, K.E.; Commean, P.K.; Hastings, M.K.; Mueller, M.J. Multi-plug insole design to reduce peak plantar pressure on the diabetic foot during walking. Med. Biol. Eng. Comput. 2008, 46, 363-371. [CrossRef]

51. Owings, T.M.; Woerner, J.L.; Frampton, J.D.; Cavanagh, P.R.; Botek, G. Custom Therapeutic Insoles Based on Both Foot Shape and Plantar Pressure Measurement Provide Enhanced Pressure Relief. Diabetes Care 2008, 31, 839-844. [CrossRef] [PubMed]

52. Burns, J.; Wegener, C.; Begg, L.; Vicaretti, M.; Fletcher, J. Randomized trial of custom orthoses and footwear on foot pain and plantar pressure in diabetic peripheral arterial disease. Diabet. Med. 2009, 26, 893-899. [CrossRef]

53. Nagel, A.; Rosenbaum, D. Vacuum cushioned removable cast walkers reduce foot loading in patients with diabetes mellitus. Gait Posture 2009, 30, 11-15. [CrossRef]

54. El-Hilaly, R.; Elshazly, O.; Amer, A. The role of a total contact insole in diminishing foot pressures following partial first ray amputation in diabetic patients. Foot 2013, 23, 6-10. [CrossRef]

55. Hellstrand Tang, U.; Zügner, R.; Lisovskaja, V.; Karlsson, J.; Hagberg, K.; Tranberg, R. Comparison of plantar pressure in three types of insole given to patients with diabetes at risk of developing foot ulcers-A two-year, randomized trial. J. Clin. Transl. Endocrinol. 2014, 1, 121-132. [CrossRef] [PubMed] 
56. Wrobel, J.S.; Ammanath, P.; Le, T.; Luring, C.; Wensman, J.; Grewal, G.S.; Najafi, B.; Pop-Busui, R. A novel shear reduction insole effect on the thermal response to walking stress, balance, and gait. J. Diabetes Sci. Technol. 2014, 8, 1151-1156. [CrossRef]

57. Arts, M.L.; de Haart, M.; Waaijman, R.; Dahmen, R.; Berendsen, H.; Nollet, F.; Bus, S.A. Data-driven directions for effective footwear provision for the high-risk diabetic foot. Diabet. Med. 2015, 32, 790-797. [CrossRef] [PubMed]

58. Chatzistergos, P.E.; Naemi, R.; Healy, A.; Gerth, P.; Chockalingam, N. Subject Specific Optimisation of the Stiffness of Footwear Material for Maximum Plantar Pressure Reduction. Ann. Biomed. Eng. 2017, 45, 1929-1940. [CrossRef] [PubMed]

59. Martinez-Santos, A.; Preece, S.; Nester, C.J. Evaluation of orthotic insoles for people with diabetes who are at-risk of first ulceration. J. Foot Ankle Res. 2019, 12, 35. [CrossRef]

60. Nouman, M.; Dissaneewate, T.; Leelasamran, W.; Chatpun, S. The insole materials influence the plantar pressure distributions in diabetic foot with neuropathy during different walking activities. Gait Posture 2019, 74, 154-161. [CrossRef]

61. Tafti, N.; Turk, S.B.; Hemmati, F.; Norouzi, E.; Sharifmoradi, K.; Karimi, M.T.; Kashani, R.V. Effect of wearing insole with different density on standing and walking plantar pressure distribution. J. Mech. Med. Biol. 2019, 19, 1950006. [CrossRef]

62. Chatzistergos, P.E.; Gatt, A.; Formosa, C.; Farrugia, K.; Chockalingam, N. Optimised cushioning in diabetic footwear can significantly enhance their capacity to reduce plantar pressure. Gait Posture 2020, 79, 244-250. [CrossRef]

63. Zwaferink, J.B.J.; Custers, W.; Paardekooper, I.; Berendsen, H.A.; Bus, S.A. Optimizing footwear for the diabetic foot: Data-driven custom-made footwear concepts and their effect on pressure relief to prevent diabetic foot ulceration. PLoS ONE 2020, 15, e0224010. [CrossRef]

64. Gao, Y.; Wang, C.; Chen, D.W.; Huang, H.; Chen, L.H.; Liu, G.J.; Lin, S.; Liu, M.; Wen, X.R.; Cho, J.H.; et al. Effects of novel diabetic therapeutic footwear on preventing ulcer recurrence in patients with a history of diabetic foot ulceration: Study protocol for an open-label, randomized, controlled trial. Trials 2021, 22, 151. [CrossRef]

65. Moreno, D.A.; Kinel, E.; Roncoletta, P.; Gnaldi, A.; Ceppitelli, C.; Belli, F.; Murdolo, G.; Vermigli, C. Data-driven CAD-CAM vs traditional total contact custom insoles: A novel quantitative-statistical framework for the evaluation of insoles offloading performance in diabetic foot. PLoS ONE 2021, 16, e0247915. [CrossRef]

66. Lavery, L.A.; LaFontaine, J.; Higgins, K.R.; Lanctot, D.R.; Constantinides, G. Shear-reducing insoles to prevent foot ulceration in high-risk diabetic patients. Adv. Ski. Wound Care 2012, 25, 519-524. [CrossRef] [PubMed]

67. Paton, J.S.; Stenhouse, E.; Bruce, G.; Jones, R. A longitudinal investigation into the functional and physical durability of insoles used for the preventive management of neuropathic diabetic feet. J. Am. Podiatr. Med. Assoc. 2014, 104, 50-57. [CrossRef]

68. Skopljak, A.; Muftic, M.; Sukalo, A.; Masic, I. Pedobarography in Diagnosis and Clinical Application. Acta Inform. Med. 2014, 22, 374-378. [CrossRef]

69. Even-Tzur, N.; Weisz, E.; Hirsch-Falk, Y.; Gefen, A. Role of EVA viscoelastic properties in the protective performance of a sport shoe: Computational studies. Bio-Med. Mater. Eng. 2006, 16, $289-299$.

70. Ryu, S.; Gil, H.; Kong, S.; Choi, Y.; Ryu, J.; Yoon, S.; Park, S.K. The effects of insole material and hardness in different plantar sites on the comfort and impact absorption. J. Ergon. Soc. Korea 2018, 37, 475-487.

71. Burnfield, J.M.; Few, C.D.; Mohamed, O.S.; Perry, J. The influence of walking speed and footwear on plantar pressures in older adults. Clin. Biomech. 2004, 19, 78-84. [CrossRef]

72. Gerych, D.; Tvrznik, A.; Prokesova, E.V.A.; Nemeckova, Z.; Jelen, K. Analysis of Peak Pressure, Maximal Force, and Contact Area Changes during Walking and Running with Conventional and Shock-Absorbing Insoles in the Combat Boots of the Czech Army. J. Mech. Med. Biol. 2013, 13, 1350042. [CrossRef]

73. Fong, D.T.P.; Lue, K.B.K.; Chung, M.M.L.; Chu, V.W.S.; Yung, P.S.H. An individually moulded insole with 5-mm medial arch support reduces peak impact and loading at the heel after a one-hour treadmill run. Gait Posture 2020, 82, 90-95. [CrossRef] [PubMed]

74. Dinato, R.C.; Ribeiro, A.P.; Butugan, M.K.; Pereira, I.L.; Onodera, A.N.; Sacco, I.C. Biomechanical variables and perception of comfort in running shoes with different cushioning technologies. J. Sci. Med. Sport 2015, 18, 93-97. [CrossRef]

75. McClymont, J.; Pataky, T.C.; Crompton, R.H.; Savage, R.; Bates, K.T. The nature of functional variability in plantar pressure during a range of controlled walking speeds. R. Soc. Open Sci. 2016, 3, 160369. [CrossRef] [PubMed]

76. Liau, B.Y.; Wu, F.L.; Lung, C.W.; Zhang, X.; Wang, X.; Jan, Y.K. Complexity-based measures of postural sway during walking at different speeds and durations using multiscale entropy. Entropy 2019, 21, 1128. [CrossRef]

77. Samson, M.M.; Crowe, A.; De Vreede, P.; Dessens, J.A.; Duursma, S.A.; Verhaar, H.J. Differences in gait parameters at a preferred walking speed in healthy subjects due to age, height and body weight. Aging Clin. Exp. Res. 2001, 13, 16-21. [CrossRef]

78. Rosenbaum, D.; Hautmann, S.; Gold, M.; Claes, L. Effects of walking speed on plantar pressure patterns and hindfoot angular motion. Gait Posture 1994, 2, 191-197. [CrossRef]

79. Escamilla-Martínez, E.; Martínez-Nova, A.; Gómez-Martín, B.; Sánchez-Rodríguez, R.; Fernández-Seguín, L.M. The effect of moderate running on foot posture index and plantar pressure distribution in male recreational runners. J. Am. Podiatr. Med. Assoc. 2013, 103, 121-125. [CrossRef] [PubMed]

80. Gefen, A. Why is the heel particularly vulnerable to pressure ulcers? Br. J. Nurs. 2017, 26, S62-S74. [CrossRef]

81. Simoneau, G.G.; Derr, J.A.; Ulbrecht, J.S.; Becker, M.B.; Cavanagh, P.R. Diabetic sensory neuropathy effect on ankle joint movement perception. Arch. Phys. Med. Rehabil. 1996, 77, 453-460. [CrossRef]

82. Williams, D.B.; Brunt, D.; Tanenberg, R.J. Diabetic neuropathy is related to joint stiffness during late stance phase. J. Appl. Biomech. 2007, 23, 251-260. [CrossRef] 
83. Lavery, L.A.; Armstrong, D.G.; Boulton, A.J. Ankle equinus deformity and its relationship to high plantar pressure in a large population with diabetes mellitus. J. Am. Podiatr. Med. Assoc. 2002, 92, 479-482. [CrossRef] [PubMed]

84. Sun, J.-H.; Cheng, B.K.; Zheng, Y.-P.; Huang, Y.-P.; Leung, J.Y.; Cheing, G.L. Changes in the thickness and stiffness of plantar soft tissues in people with diabetic peripheral neuropathy. Arch. Phys. Med. Rehabil. 2011, 92, 1484-1489. [CrossRef]

85. Klaesner, J.W.; Hastings, M.K.; Zou, D.; Lewis, C.; Mueller, M.J. Plantar tissue stiffness in patients with diabetes mellitus and peripheral neuropathy. Arch. Phys. Med. Rehabil. 2002, 83, 1796-1801. [CrossRef]

86. Bai, P.; Phua, K.; Hardt, T.; Cernadas, M.; Brodsky, B. Glycation alters collagen fibril organization. Connect. Tissue Res. 1992, 28, 1-12. [CrossRef]

87. Grant, W.P.; Sullivan, R.; Sonenshine, D.E.; Adam, M.; Slusser, J.H.; Carson, K.A.; Vinik, A.I. Electron microscopic investigation of the effects of diabetes mellitus on the Achilles tendon. J. Foot Ankle Surg. 1997, 36, 272-278. [CrossRef]

88. Kim, M.S.; Park, C.C.; Chowdhury, S.R.; Kim, G.H. Physical properties of ethylene vinyl acetate copolymer (EVA)/natural rubber (NR) blend based foam. J. Appl. Polym. Sci. 2004, 94, 2212-2216. [CrossRef]

89. Morita, J.; Ando, Y.; Komatsu, S.; Matsumura, K.; Okazaki, T.; Asano, Y.; Nakatani, M.; Tanaka, H. Mechanical Properties and Reliability of Parametrically Designed Architected Materials Using Urethane Elastomers. Polymers 2021, 13, 842. [CrossRef]

90. Wang, W.; Gong, W.; Zheng, B. Improving viscoelasticity and rebound resilience of crosslinked low-density polyethylene foam by blending with ethylene vinyl acetate and polyethylene-octene elastomer. J. Vinyl Addit. Technol. 2016, 22, 61-71. [CrossRef]

91. Kwon, M.J.; Lim, D.H.; Choi, I.C.; Kwon, H.-W.; Ha, C.-S. Preparation and properties of ethylene-vinyl acetate copolymer-based blend foams. J. Elastomers Plast. 2021, 53, 68-82. [CrossRef]

92. Pratt, D.J.; Rees, P.H.; Rodgers, C. Technical Note: Assessment of Some Shock Absorbing Insoles. Prosthet. Orthot. Int. 1986, 10, 43-45. [CrossRef]

93. Dutta, J.; Naskar, K. Investigation of morphology, mechanical, dynamic mechanical and thermal behaviour of blends based on ethylene vinyl acetate (EVA) and thermoplastic polyurethane (TPU). RSC Adv. 2014, 4, 60831-60841. [CrossRef]

94. Gama, N.V.; Ferreira, A.; Barros-Timmons, A. Polyurethane foams: Past, present, and future. Materials 2018, 11, 1841. [CrossRef] [PubMed]

95. Gama, N.; Godinho, B.; Barros-Timmons, A.; Ferreira, A. Insights into PU/EVA Blends Produced Using Industrial Residues Towards Eco-efficient Materials. J. Polym. Environ. 2021. [CrossRef]

96. Junior, C.Z.P.; Peruchi, R.S.; de Carvalho Fim, F.; Soares, W.D.O.S.; da Silva, L.B. Performance of ethylene vinyl acetate waste (EVA-w) when incorporated into expanded EVA foam for footwear. J. Clean. Prod. 2021, 317, 128352. [CrossRef]

97. Dhanapal, D.; Melese, B.; Shawel, L.; Sanmugam, K. Research comparison of foot plantar pressure on polyurethane visco elastic foam insole and eva insole materials. In Proceedings of the 8th International Conference on Advanced Materials and Systems, Bucharest, Romania, 1-3 October 2020.

98. Mohamed, O.; Cerny, K.; Rojek, L.; Herbert, K.; Turner, R.; Waistell, S. The effects of Plastazote ${ }^{\circledR}$ and Aliplast ${ }^{\circledR} /$ Plastazote ${ }^{\circledR}$ orthoses on plantar pressures in elderly persons with diabetic neuropathy. JPO J. Prosthet. Orthot. 2004, 16, 55-63. [CrossRef] 